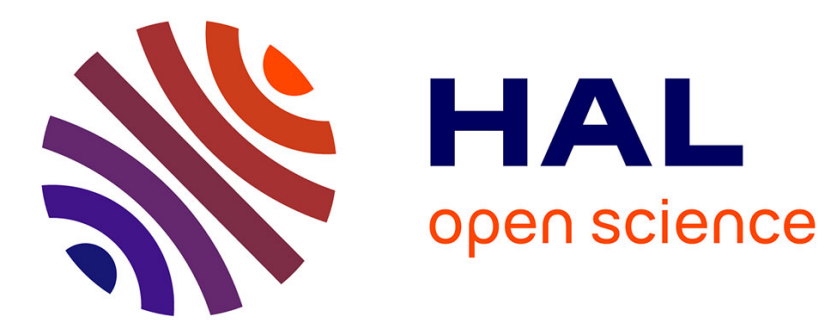

\title{
Arctic ozone loss in Siberia in 2011 and 2012
}

Valery Dorokhov, N. Tsvetkova, Vladimir Yushkov, H. Nakajima, G. Ivlev, A. Makshtas, N. Tereb, Florence Goutail, Andrea Pazmino, Jean-Pierre

\section{Pommereau}

\section{- To cite this version:}

Valery Dorokhov, N. Tsvetkova, Vladimir Yushkov, H. Nakajima, G. Ivlev, et al.. Arctic ozone loss in Siberia in 2011 and 2012. Atmospheric Measurement Techniques, 2013, 6 (2), pp.2955-2978. 10.5194/amtd-6-2955-2013 . hal-00808110

\section{HAL Id: hal-00808110 https://hal.science/hal-00808110}

Submitted on 17 Apr 2016

HAL is a multi-disciplinary open access archive for the deposit and dissemination of scientific research documents, whether they are published or not. The documents may come from teaching and research institutions in France or abroad, or from public or private research centers.
L'archive ouverte pluridisciplinaire HAL, est destinée au dépôt et à la diffusion de documents scientifiques de niveau recherche, publiés ou non, émanant des établissements d'enseignement et de recherche français ou étrangers, des laboratoires publics ou privés. 


\section{Arctic ozone loss in Siberia in 2011 and 2012}

V. Dorokhov ${ }^{1}$, N. Tsvetkova ${ }^{1}$, V. Yushkov ${ }^{1}$, H. Nakajima ${ }^{2}$, G. Ivlev ${ }^{3}$, A. Makshtas ${ }^{4}$, N. Tereb $^{5}$, F. Goutail ${ }^{6}$, A. Pazmino ${ }^{6}$, and J.-P. Pommereau ${ }^{6}$

${ }^{1}$ Central Aerological Observatory, Moscow, Russia

${ }^{2}$ National Institute for Environmental Studies, Tsukuba, Japan

${ }^{3}$ V. E. Zuev Institute of Atmospheric Optics, Tomsk, Russia

${ }^{4}$ Arctic and Antarctic Research Institute, St. Petersburg, Russia

${ }^{5}$ Institute of Experimental Meteorology, Obninsk, Russia

${ }^{6}$ LATMOS, CNRS-Université de Versailles St Quentin, Guyancourt, France

Received: 8 February 2013 - Accepted: 12 March 2013 - Published: 22 March 2013

Correspondence to: H. Nakajima (nakajima@nies.go.jp)

Published by Copernicus Publications on behalf of the European Geosciences Union.

\section{Title Page}

Abstract

Introduction

Conclusions

References

Tables

Figures

14

4

Back

Close

\section{Full Screen / Esc}

Printer-friendly Version

Interactive Discussion

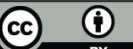




\section{Abstract}

The atmospheric ozone plays an important role in understanding of the processes occurring in the atmosphere and changes in the climate. Total ozone observations in Siberia were performed by Brewer MKIV No. 049 spectrophotometer in Tomsk, 5 Western Siberia and SAOZ UV-Vis spectrometers deployed along the Arctic Circle in Salekhard aerological station since 1998 and Zhigansk aerological station in Eastern Siberia since 1991. We also use 2Z-ECC ozonesondes for ozone profile observations in winter-spring period at the Salekhard aerological station at the in Western Siberia and ECC-6A sondes at the drifting North Pole station NP-38 in the Central Arctic area.

During the winter-spring season in 2011 , Arctic ozone in the $19-21 \mathrm{~km}$ altitude region was observed to be more than $70 \%$ less that typical values. In the winter-spring of 2012, on the other hand, Arctic conditions were overall much warmer than in 2011, and no evidence of significant ozone loss was seen above the Asiatic regions of Russian Federation.

15 The aim of the paper is to describe which and where these measurements were carried out and illustrate their performances by some examples of ozone data measured in Western and Eastern Siberia, Russia such as that which occurred in the winter-spring season of 2011.

\section{Introduction}

20 Monitoring and evaluations of the ozone layer are carried out using Brewer MKII spectrophotometer (Dorokhov, 1990; Kerr et al., 1990; Dorokhov et al., 1995; Nerushev and Tereb, 2003), Brewer MKIV spectrophotometer (Belan et al., 2008, 2011), SAOZ spectrometer (Pommereau and Goutail, 1988; Goutail et al., 1994, 2005; Hendrick et al., 2011), ozonesonde (Rex et al., 1997, 2006; Sugita et al., 2006; Yushkov et al., 2002; Tsvetkova et al., 2002, 2007), filter M-124 ozonometer (Bazhenov and Burlakov, 2011), and satellite instruments. For ozone monitoring in Russia we are using Brewer

\section{6}

\section{AMTD}

6, 2955-2978, 2013

Arctic ozone loss in Siberia in 2011 and 2012

\section{Dorokhov et al.}

\section{Title Page}

Abstract

Conclusions

References

Tables

Figures

14

$\Delta$

4

Back

Close

\section{Full Screen / Esc}

Printer-friendly Version

Interactive Discussion

$>$

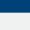

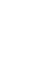

(n)

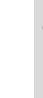

.


spectrophotometers for total ozone observations at Kislovodsk $\left(43.7^{\circ} \mathrm{N}, 42.7^{\circ} \mathrm{E}\right), \mathrm{Ob}-$ ninsk $\left(55.1^{\circ} \mathrm{N}, 36.6^{\circ} \mathrm{N}\right)$ and Tomsk $\left(56.5^{\circ} \mathrm{N}, 85.1^{\circ} \mathrm{E}\right)$. Total ozone and $\mathrm{NO}_{2}$ measurements from SAOZ UV-Vis spectrometers are carried out at the Salekhard aerological station $\left(66.5^{\circ} \mathrm{N}, 66.7^{\circ} \mathrm{E}\right)$ in the Western Siberia and Zhigansk aerological station (66.8, 5 123.4) in Eastern Siberia. Ozone profile measurements are carried out at Salekhard aerological station and NP-38 station in 2011. Salekhard is currently the only place for regular vertical ozone profile observations in winter-spring conditions in Russian Federation. The map of the Brewer, SAOZ and ozonesonde stations in Russia in 2012 is shown in Fig. 1.

\section{The discovery}

\subsection{Brewer ozone spectrophotometer}

The Brewer ozone spectrophotometer was developed in the 1970s and introduced into the global network in 1982 to measure total ozone in the atmosphere. The Brewer instrument derives total column ozone from UV measurements using two operational 15 modes: observing either direct sunlight (DS) or zenith sky (ZS) scattered sunlight. The purpose of the spectrometer optical subassembly is to accept light through the entrance slit and disperse it into a high-quality spectrum along the exit-slit focal plane. The spectrometer is a modified Ebert type with focal length $16 \mathrm{~cm}$, and aperture ratio $\mathrm{f} / 6$. Six exit slits are positioned along the exit focal plane at the ozone or $\mathrm{NO}_{2}$ operat20 ing wavelengths $303.2 \mathrm{~nm}$ (302.1 for mercury wavelength calibration), $306.3 / 431.4 \mathrm{~nm}$, $310.1 / 437.3 \mathrm{~nm}, 313.5 / 442.8 \mathrm{~nm}, 316.8 / 448.1 \mathrm{~nm}$ and $320.1 / 453.2 \mathrm{~nm}$ with 0.6/0.9 nm resolution. Wavelength is adjusted by rotating the grating with a stepper motor which drives a micrometer acting on a lever arm. The wavelength calibration procedure is capable of measuring the wavelength setting with a precision of $0.0001 \mathrm{~nm}$, and of controlling the wavelength setting to $0.006 \mathrm{~nm}$ in the UV region. At the exit of the spectrometer is a cylindrical mask which exposes only one wavelength slit at a time. The
AMTD

6, 2955-2978, 2013

Arctic ozone loss in Siberia in 2011 and 2012

V. Dorokhov et al.

\section{Title Page}

Abstract

Introduction

Conclusions

Tables

References

Figures

14

$>$ I
4

Back

Close

\section{Full Screen / Esc}

Printer-friendly Version

Interactive Discussion

$>$

(n)

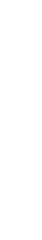


mask is positioned by a stepper motor which cycles through all five operating wavelengths, approximately once per second.

The Brewer total ozone measurements at Yakutsk $\left(62.0^{\circ} \mathrm{N}, 129.7^{\circ} \mathrm{E}\right)$, Eastern Siberia have been conducted with ground-based Brewer spectrophotometer since

5 1992. The data of total ozone observations at Yakutsk station during winter-spring periods in 1992-2006 provided many days of total ozone observations inside and outside the polar vortex and allowed an investigation of the long-term variability of the total ozone in different seasons. The calibrations in Yakutsk $(1996,2001,2005)$ using traveling reference instrument Brewer MKII No 017 have provided the Brewer MKII No 045 to 10 be a stable and well-maintained spectrophotometer. Continuing calibrating the Brewer spectrophotometers using the traveling standard will help maintaining the high-quality total ozone observations with the Brewer network in Russia.

The Brewer MKII No 043 spectrophotometer is installed at Kislovodsk high-mountain station of Obukhov Institute of Atmospheric physics Russia Academy of Science 15 (KHMS) and is located at 2070 meters above sea level in the Northern Caucasus, Russia. Brewer MKII No 044 spectrophotometer is used for total ozone measurements at the Institute of Experimental Meteorology (IEM) at Obninsk city near Moscow. Total ozone observations by the Brewer MKIV No 049 spectrophotometer at Tomsk, Central Siberia, have been conducted since 2003. All Russian Brewer instruments in 2012 were calibrated by International Ozone Services Incorporated (IOS), Toronto, Ontario, Canada using traveling Brewer standard spectrophotometer in IEM, Obninsk, in September 2012. IOS provides worldwide ozone and UV calibration services to customers with Brewer Ozone Spectrophotometer instruments.

\subsection{SAOZ UV-Vis spectrometer}

25 Ozone measurements in the visible Chappuis bands between 450-600 nm for the first time allow the continuous monitoring of the species throughout the year at the latitude of the polar circle, in all weather conditions. The first paper about SAOZ observations in the Arctic area was published by Pommereau and Goutail in (1988). SAOZ (Systeme

\section{AMTD}

6, 2955-2978, 2013

Arctic ozone loss in Siberia in 2011 and 2012

V. Dorokhov et al.

\section{Title Page}

Abstract Introduction

Conclusions

Tables

References

Figures

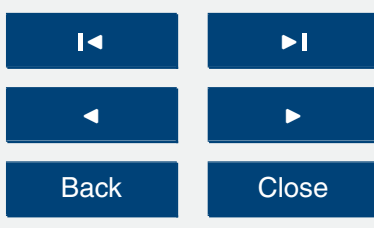

Full Screen / Esc

Printer-friendly Version

Interactive Discussion 
d'Analyse par Observation Zenitale) is a UV-visible diode array spectrometer developed at the Service d'Aeronomie, CNRS, France in the late $80 \mathrm{~s}$, after the discovery of the ozone hole by Farman et al. (1985), for monitoring stratospheric ozone $\left(\mathrm{O}_{3}\right)$ and nitrogen dioxide $\left(\mathrm{NO}_{2}\right)$. The SAOZ is manufactured at the Laboratory for Atmospheric 5 Research (LATMOS) for measuring total ozone, nitrogen dioxide and some other atmospheric trace gases $\left(\mathrm{BrO}, \mathrm{O}_{4}\right)$. The spectrometer uses the technique of measurements in the ultraviolet and visible wavelengths of sun in the registration of the zenith sky.

The SAOZ consists of a commercial Jobin-Yvon CP200 flat field spectrometer equipped with a holographic $360 \mathrm{grmm}^{-1}$ grating and a Hamamatsu 1024 diode ar10 ray uncooled detector, with a 50 micron entrance slit allowing an average resolution on the order of $1 \mathrm{~nm}$ in the range $300-600 \mathrm{~nm}$. The spectrometer is housed in a dust- and water-proof container with a quartz window to enable measurements from the zenith sky. The instrument is driven by a PC (with Windows 95 operating system) and records and analysis the spectra in real time. Measurements are performed from sunrise to 15 sunset, until the Solar Zenith Angle (SZA) reaches 94. The exposure time is adjusted automatically between $0.1 \mathrm{~s}$ to $60 \mathrm{~s}$ in order to optimize the signal, and the spectra are added to memory during a $60 \mathrm{~s}$ duty cycle. The dark current is measured each time the duration of exposure changes, and is then subtracted. Averages of ozone and $\mathrm{NO}_{2}$ morning and evening vertical columns are measured between 87 and 91 SZA. SAOZ performance has been continuously evaluated during all NDACC UV intercomparison campaigns. The wavelength range of the SAOZ instrument is in the Chappuis band of ozone absorption, with a spectral resolution of $1 \mathrm{~nm}$ for version V-1024. Measurement accuracy is $6 \%$ for total ozone and $10 \%$ for nitrogen dioxide. Data for the atmospheric content of $\mathrm{O}_{3}$ and $\mathrm{NO}_{2}$ measured by $\mathrm{SAOZ}$ spectrometers are available at the World 25 SAOZ database, since 1988 from Dumont d'Urville station in the Southern Hemisphere, since 1989 from the Sodankylä observatory in Finland, and from additional SAOZ stations in 1990-1991. The first Asiatic SAOZ station started operation in December of 1991 at Zhigansk aerological station, Eastern Siberia. A SAOZ spectrometer has been operating at Salekhard aerological station, Western Siberia since 1998.

\section{AMTD}

6, 2955-2978, 2013

Arctic ozone loss in Siberia in 2011 and 2012

V. Dorokhov et al.

\section{Title Page}

Abstract Introduction

Conclusions

Tables

References

Figures

14

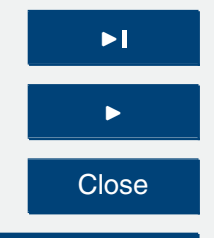

Full Screen / Esc

Printer-friendly Version

Interactive Discussion 


\subsection{ECC oznesonde}

The Electrochemical Concentration Cell (ECC) ozonesonde was originally built by Walter Komhyr in 1969. The ozonesonde is a lightweight, balloon-borne instrument that is mated to a conventional meteorological radiosonde. As the balloon carrying the instru5 ment package ascends through the atmosphere, and the ozonesonde telemeters to a ground receiving station information on ozone and standard meteorological quantities such as pressure, temperature and humidity. The balloon will ascend to altitudes of about $35 \mathrm{~km}$ before it bursts. The heart of the ozonesonde is an electrochemical concentration cell (ECC) that senses ozone as is reacts with a dilute solution of potassium 10 iodide to produce a weak electrical current proportional to the ozone concentration of the sampled air.

The first ozonesonde vertical profile measurements in Russia were started at Heiss Island, Franz Josef Land in the Central Arctic in 1989 as part of joint project between the Central Aerological Observatory and University of Wyoming. This activity took place 15 in 1989-1992. Afterwards, ozone profile observations were carried out at the Yakutsk aerological station $\left(62.0^{\circ} \mathrm{N}, 129.7^{\circ} \mathrm{E}\right)$ from December 1994 until 2006, Rylsk $\left(51.6^{\circ} \mathrm{N}\right.$, $\left.34.7^{\circ} \mathrm{E}\right)$ in $1997-1998$ and the Salekhard aerological station $\left(66.5^{\circ} \mathrm{N}, 66.7^{\circ} \mathrm{E}\right)$ since January 1997. At the present time, the Salekhard aerological station is the only place for ozone profile observations in Russia. Vertical ozone profile observations in Yakutsk,

20 Eastern Siberia were carried out in 1995-2002 under a joint ozone project between NIES, Japan and CAO, Russia. This project was closed in 2002. In 2003-2005 vertical ozone profile measurements were made at the Yakutsk aerological station as part of the EU funded project Quantitative understanding of ozone losses by bipolar investigations (QUOBI). This station was closed in 2006 and ozone profile observations in the Arctic 25 regions of Russia are now possible at Salekhard, Western Siberia, and NP-38 drifting station (2011), Central Arctic.

\section{AMTD}

6, 2955-2978, 2013

Arctic ozone loss in Siberia in 2011 and 2012

V. Dorokhov et al.

\section{Title Page}

Abstract Introduction

Conclusions

Tables

References

Figures

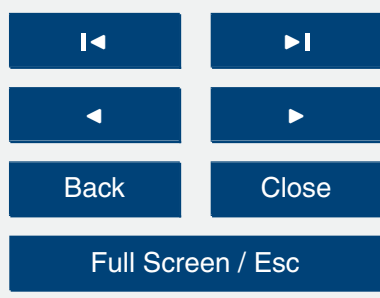

Printer-friendly Version

Interactive Discussion 


\section{Analysis}

\subsection{Brewer total ozone observations in Central Siberia}

Total ozone in the middle of March 2011 was less than usual about 130-150 Dobson Unit (DU), and the negative ozone anomaly has been observed even in the first 5 decade of April. Such a large and long listed Arctic ozone loss was possible due to the significant denitrification in the Arctic stratosphere at abnormally low stratospheric temperature and formation of polar stratospheric clouds (Manney et al., 2011; Balis et al., 2011). The level of total ozone over the territory of the Russian Federation in 2011 was significantly lower than that observed in the late 1970s, but above the minimum in the late 1990s. Spring time anomaly in high latitudes has been one of the most significant ozone anomalies in the Northern Hemisphere for the time more than half a century of observations. This is a record amount of ozone loss over the entire period of observations in the Arctic. The previous record was observed in winter-spring season of 2004/2005 and was 116 DU. The Arctic ozone loss 2011 was well observed by the Brewer, SAOZ and 2Z-ECC ozonesonde network at the polar latitudes in the Russian Federation.

The Brewer spectrophotometers were originally designed for total ozone measurements. In 2011 we have only one Brewer spectrophotometer in the Asiatic part of Russia, which was nearby the Arctic area where the Arctic ozone losses have been observed. The low total ozone was measured in Tomsk by Brewer MKIV No 049 spectrophotometer between in the first two weeks of April. In March-April 2011 a very low total ozone observations were carried out at Brewer stations in Scandinavia. The low ozone values were registrated in Finland at Sodankulä station. The Sodankylä $\left(67.4^{\circ} \mathrm{N}\right.$, $\left.26.6^{\circ} \mathrm{E}\right)$ total ozone measurements have been performed with a Brewer spectropho-

tometer since 1988. On 9 March 2011, the Brewer MKII No 037 instrument at the north-

ern Polar Circle measured as low as 242 DU. The Brewer MKII spectrophotometer in Andøya, Norway $\left(69.3^{\circ} \mathrm{N}, 16.0^{\circ} \mathrm{E}\right)$, operated by NILU and the University of Troms $\varnothing$, observed the same low total ozone values in in middle of March. Unusually low ozone

Arctic ozone loss in Siberia in 2011 and 2012

V. Dorokhov et al.

\section{Title Page}

Abstract

\section{Full Screen / Esc}

Printer-friendly Version

Interactive Discussion 
columns were measured from mid-March to first decade of April 2011 at all Arctic stations compared to the previous years. The low total ozone $259 \mathrm{DU}$ was measured at the Sammit station $\left(72.6^{\circ} \mathrm{N}, 38.5^{\circ} \mathrm{W}\right)$ in Greenland on 28 March 2011. The Brewer spectrophotometer is used in the Canadian stratospheric ozone and UV monitoring 5 program, with 12 sites established in Canada that routinely collect and process data on a daily basis. The instruments measure total ozone and spectral UV irradiation (290$325 \mathrm{~nm}$ ) every 10-20 min during the daytime. The Brewer spectrophotometers in the Northern Canada measured the total ozone values which were $20-25 \%$ below the climatic norm at the end of February to mid-March 2011.

10 The result of the Brewer MKIV No 049 total ozone measurements in Tomsk in 20032012 are presented in Fig. 2. The result of the Brewer total ozone measurements in Obninsk and Tomsk in 2011 are shown in Fig. 3. The Brewer MKIV No 049 spectrophotometer at Tomsk station in Central Siberia is the best instrument for good quality and high precision ground-based total ozone measurements in the Asiatic part of Russia. The Brewer Data Management System (BDMS) is located with the World Ozone and Ultraviolet Radiation Data Centre (WOUDC) and both are located in Toronto and operated by Environment Canada staff. The BDMS acts as the permanent archive of Canadian Brewer data. Although the main focus of the BDMS initially was for Canadian data only, this system is now available to the international Brewer community. The data of the Brewer spectrophotometer total ozone measurements in Russia are available from the WOUDC database http://www.woudc.org/data_e.html.

\subsection{SAOZ network in Russia}

An unprecedented depletion of Earth's protective ozone layer above the Arctic in the 2010/2011 Arctic winter and spring has been documented (Manney et al., 2011), caused by an unusually prolonged period of low temperatures in the stratosphere. The unusually large Arctic ozone loss in 2011 appears to resulting from an extreme meteorological event and there is no indication of possible strengthening related to climate change. Unusually low ozone columns were measured from mid-March to late March

\section{AMTD}

6, 2955-2978, 2013

Arctic ozone loss in Siberia in 2011 and 2012

V. Dorokhov et al.

\section{Title Page}

Abstract Introduction

Conclusions

Tables

References

Figures

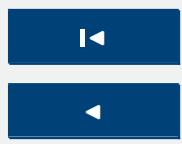

$\Delta$

Back

Close

\section{Full Screen / Esc}

Printer-friendly Version

Interactive Discussion
$>$ 
and first decade of April 2011 compared to the previous years (Pommereau et al., 2012).

In collaboration with the French CNRS within the frame of the Network for the Detection of Atmospheric Composition Change (NDACC), two SAOZ instruments are op5 erated at the polar circle where those instruments allow year round observations: in Zhigansk in Eastern Siberia operating since 1991 and in Salekhard in Western Siberia since 1998. Altogether these instruments cover a vast polar region in the Northern Hemisphere allowing the monitoring of amplitude of Arctic ozone destruction each year. As an example, those instruments significantly contributed to the quantification of the 10 unprecedented loss in 2011 caused by a combination of long lasting denoxified vortex resulting in a record daily loss rate never seen before in the Arctic. Indeed as one may see in the WOUDC ozone mapping, the ozone depleted polar vortex passed over Salekhard and Zhigansk in late March-early April 2011 where losses of about $40 \%$ were observed above the two stations located at the northern Polar Circle.

15 The total ozone reduction in the vortex conditions was $38 \pm 3 \%$ or $165 \mathrm{DU}$ in 2011 with the loss rate $0.2 \%$ per day until mid-February and $0.8 \%$ per day between 20 February and 20 March 2011. The total ozone was as low as 235 DU at Zhigansk on 23 March 2011 and 242 DU in Salekhard on 31 March 2011. The SAOZ spectrometer observed low total ozone values 250-270 DU in Salekhard during the first week of 20 April 2011 when the polar vortex was still located in this area. The SAOZ instrument at Zhigansk station did not measure low total ozone at this time. The SAOZ low total ozone levels in winter-spring period of 2011 are well documented in Fig. 4 for Salekhard and Zhigansk. The total ozone reduction in the vortex conditions in 2012 was about $14 \% \pm 4 \%$ or $60 \mathrm{DU}$ and the loss rate $0.35 \%$ per day between end of December and 25 early February 2012.

The SAOZ long-term total ozone and $\mathrm{NO}_{2}$ dataset at Zhigansk aerological station in 1991-2011 and at Salekhard aerological station in 2001-2011 are presented in Fig. 5. The total ozone loss for some days in January and March 2011 are shown in Fig. 6 for Salekhard and Zhigansk stations, when the polar vortex was located above the
AMTD

6, 2955-2978, 2013

Arctic ozone loss in Siberia in 2011 and 2012

V. Dorokhov et al.

\section{Title Page}

Abstract Introduction

Conclusions

Tables

References

Figures

14

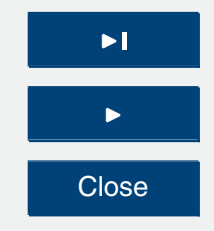

Back

Close

\section{Full Screen / Esc}

Printer-friendly Version

Interactive Discussion 
stations. The measurements of total ozone and $\mathrm{NO}_{2}$ by $\mathrm{SAOZ}$ instruments in Russia, providing data all year round, cover a vast polar regions in the Northern Hemisphere. The data of total ozone and $\mathrm{NO}_{2}$ observations by the SAOZ UV-Vis spectrometers in Russia are submitted and presented at the World SAOZ database in France http:

5 //saoz.obs.uvsq.fr/SAOZ-RT.html and at the NDACC database http://www.ndsc.ncep. noaa.gov/.

\subsection{Ozonesounding in Siberia}

At the Yakutsk aerological stations coordinated ozonesonde flights were started in late 1994. At the same time coordinated measurements of vertical ozone distribution were made by European scientists at 30 stations of the Northern Hemisphere in the frame of international program on investigation of mechanisms of ozone layer depletion. Ozonesonde flights were performed in a manner to monitor the changes of ozone concentration in the same air masses. For this purpose the local time and date of ozonesonde launches were determined using the daily forecasts of air mass trajectories. Using the data of balloon ozonesounding at Yakutsk quantitative estimation of ozone depletion in the lower stratosphere were made for spring months of 1995-1997 inside and outside the polar vortex. Comparison of given estimations of daily ozone variations with theoretical rates of photochemical ozone reduction make it possible to conclude about chemical ozone depletion mechanism during spring months inside the polar vortex at the territory of Eastern Siberia.

It is well established that extensive depletion of ozone, initiated by heterogeneous reactions on polar stratospheric clouds can occur in both the Arctic and Antarctic lower stratosphere. Moreover, it has been shown that ozone loss rates in the Arctic region in recent years reached values comparable to those over the Antarctic. But until now 25 the accumulated ozone losses over the Arctic have been much smaller than those over the Antarctic, mainly because the period of Arctic ozone loss has not persisted far into springtime. If the apparent cooling trend in the Arctic lower stratosphere is real, more dramatic ozone losses may occur in the future (Manney et al., 1994, 1995;
AMTD

6, 2955-2978, 2013

Arctic ozone loss in Siberia in 2011 and 2012

V. Dorokhov et al.

Title Page

Abstract

Conclusions

Tables References Figures

14 $\rightarrow$

4

Back

Close

\section{Full Screen / Esc}

Printer-friendly Version

Interactive Discussion

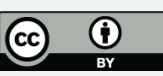


von der Gathe et al., 1995; Rex et al., 1997; Tsvetkova et al., 1997; Solomon, 1999). The model calculations of the rate of chemical ozone loss in the lower stratosphere using the chemical transport model have proved to be underestimated relative to the experimental observation in Eastern Siberia within the zone of action of the circum-

5 polar stratospheric vortex. This discrepancy may have resulted from the fact that the process of intensive ozone depletion during the spring months due to the formation of polar stratospheric clouds of orographic nature not only over Scandinavian mountains, but also over the Urals, has not been taken into account in the model concerned. To verify this hypothesis, balloon-borne measurements were carried out of ozone vertical 10 distribution at Salekhard station located on the lee side at air masses transport in the atmosphere with westerly winds. The measurements at Yakutsk and Salekhard stations were performed during 1996/1997 season, i.e. from the beginning of the formation of the polar stratospheric cyclone and during the period of its intensive development and destruction in winter and spring.

15 The measurements of the vertical ozone distribution were so coordinated with balloon-borne measurements conducted at other European stations as to help trace ozone changes within the same air masses of the Northern Hemisphere. Balloonborne ozone data and weather data on temperature and potential vorticity fields have been analyzed to show that during the spring months of 1998 and 1999 in contrast to the same period of 1995 and 1996, no intense processes of the chemical loss of stratospheric ozone had been observed over the polar latitudes of Western and Eastern Siberia. Such an interannual variability of ozone amount in the lower stratosphere, within the zone of action of the northern circumpolar vortex, is due to the weather conditions of its formation.

25 During the winter-spring season of 2011 the observed ozone decrease exceeded $70 \%$ within the 19-21 km altitude range. During the winter-spring season of 2012 we have seen usual Arctic conditions and no significant ozone loss above Salekhard station. Ozonesonde data from the Salekhard station during the Arctic winter-spring season of 2010/2011 and 2011/2012 are available from the NDACC database. Chemical

AMTD

6, 2955-2978, 2013

Arctic ozone loss in Siberia in 2011 and 2012

V. Dorokhov et al.

Title Page

Abstract Introduction

Conclusions

Tables

References

Figures

14 $\Delta$

4

Back

Close

Printer-friendly Version

Interactive Discussion

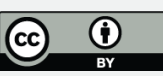


ozone destruction occurs over the Arctic and Antarctic regions in local winter-spring. In the Antarctic, essentially complete removal of lower-stratospheric ozone currently results in an ozone hole every year, whereas in the Arctic, ozone loss is highly variable from year to year and has until now been much more limited. We study the Arctic ozone 5 losses using the results of the ozonesonde observations in the Arctic during the Match campaigns in 1994-2012. The two main aims of Match campaigns are to measure the chemical ozone loss in polar regions, and to check our understanding of the underlying processes. The idea of Match campaign is to probe, i.e. to determine the ozone content of, a lot of air parcels twice during their way through the atmosphere. This is achieved 10 by coordinating the soundings roughly in the following way. The trajectories (transport paths) of air masses, which had been measured by ozonesondes previously, are analyzed and forecasted by meteorologists at the Freie Universität Berlin (FU Berlin). These trajectories are checked for cases when such an air mass reaches the vicinity of one of the participating measuring sites (ozonesonde station) within 10 days. The staff to examine the same air mass for a second time. A decrease in the ozone concentration within the time period of the two sonde flights can then be attributed to chemical ozone depletion. Due to the great number of sonde pairs, statistically significant ozone loss rates can be determined.

Some results of ozone sounding at the Salekhard aerological station in polar vortex conditions in March-April 2011 and February 2012 are shown in Fig. 7. The total 150 ozonesondes were launched at Yakutsk aerological station in Eastern Siberia during the winter-spring season of 1994-2006 and 250 ozonesondes, version 2Z-ECC, were used for vertical ozone profile observations at the Salekhard aerological station in Western Siberia, Russia. The data of the Salekhard ozonesonde measurements in 2005-2012 are available from the NDACC database ftp://ftp.cpc.ncep.noaa.gov/ndacc/ station/salekhar/ames/o3sonde/.
AMTD

6, 2955-2978, 2013

Arctic ozone loss in Siberia in 2011 and 2012

V. Dorokhov et al.

Title Page

Abstract Introduction

Conclusions

Tables

References

Figures

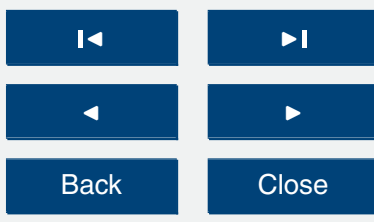

Full Screen / Esc

Printer-friendly Version

Interactive Discussion

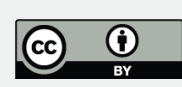




\section{Conclusions}

Brewer spectrophotometers detected anomalously low total ozone at Tomsk and Obninsk stations in March-April 2011. The January-March 2012 total ozone observations from these Brewer spectrophotometers in Russia did not show any episodes of unusu5 ally low total ozone, nor did those from the Brewer station in Kislovodsk in contrast with measurements from the SAOZ spectrometers at the NDACC stations in Salekhard ( $40 \%$ in March) and Zhigansk (up to $40 \%$ on some days in March and April 2011). The measurements of total ozone and $\mathrm{NO}_{2}$ by $\mathrm{SAOZ}$ instruments in Russia provide data all year round. The unprecedented depletion of Earth's protective ozone layer above the Arctic in winter and spring 2011, caused by an unusually prolonged period of low temperatures in the stratosphere, is reflected in the measurements presented here. In January-March 2012, SAOZ observations in Russia did not show any evidence of unusually low Arctic ozone. During the winter-spring season in 2011, Arctic ozone in the $19-21 \mathrm{~km}$ altitude region was observed to be more than $70 \%$ less that typical values. In the winter-spring of 2012, on the other hand, Arctic conditions were overall much warmer than in 2011, and no evidence of significant ozone loss was seen above the Salekhard area.

Acknowledgements. The authors thank Tatiana Popova, Vladimir Balashov from Salekhard aerological station, Western Siberia for SAOZ and ozonesonde operation in 1997-2012. We thank Vasily Lyulkin from Zhigansk aerological station, Eastern Siberia for SAOZ operation in 2005-2012. This work was partly supported by the French CNES and CNRS/INSU within the NDACC/OVSQ programme and by Roshydromet, Russia. We thank the staff from Droplet Measurement Technologies, Boulder, Colorado, USA for discussions and help with new ECC ozonesonde 2Z-V7 activation. We also thank Gloria L. Manney from NorthWest Research Associates, NM, USA and Peter von der Gathen from Alfred Wegener Institute for Polar and Marine Research, Potsdam, Germany for discussions and help during the initial phase of paper preparation. This project was partly supported by National Institute for Environmental Studies, Tsukuba, Japan.
AMTD

6, 2955-2978, 2013

Arctic ozone loss in Siberia in 2011 and 2012

V. Dorokhov et al.

\section{Title Page}

Abstract

Conclusions

Tables

References

Figures

I

4

$\Delta$

4

Back

\section{Full Screen / Esc}

Printer-friendly Version

Interactive Discussion 


\section{References}

Balis, D., Isaksen, I. S. A., Zerefos, C., Zyrichidou, I., Eleftheratos, K., Tourpali, K., Bojkov, R., Rognerud, B., Stordal, F., Søvde, O. A., and Orsolini, Y.: Observed and modelled record ozone decline over the Arctic during winter/spring 2011, Geophys. Res. Lett., 38, L23801, 5 doi:10.1029/2011GL049259, 2011.

Bazhenov, O. E. and Burlakov, V. D.: Anomalous decrease of the level of the total ozone content over Tomsk and northern territory of Russia in March-April 2011, Atmos. Ocean. Opt., 24, 915-919, 2011.

Belan, B. D., Ivlev, G. A., and Sklyadneva, T. K.: Variations of UV-B radiation in Tomsk in 20032007, Atmos. Ocean. Opt., 21, 535-539, 2008.

Belan, B. D., Ivlev, G. A., and Sklyadneva, T. K.: Influence of a city on the incoming UV radiation from results of many-year monitoring near Tomsk-city, Atmos. Ocean. Opt., 24, 1113-1119, 2011.

Dorokhov, V. M.: Observations of the total ozone content inthe arctic over Heiss Island $\left(81^{\circ} \mathrm{N}\right)$ in winter 1989, Atmos. Ocean. Opt., 3, 89-94, 1990.

Dorokhov, V. M. and Potapova, T. E.: Observation of total content of atmospheric ozone in high Arctic latitudes, Atmos. Ocean. Opt., 8, 451-454, 1995.

Dorokhov, V. M., Dolgii, S. V., Ivanov, Yu. S., and Sitnikova, V. I.: Observation of the total ozone content in the atmosphere over the Arctic during the polar night of 1991, Atmos. Ocean. Opt.,

20 4, 601-603, 1991.

Dorokhov, V. M., Potapova, T. E., Goutail, F., and Pommereau, J.-P.: Studying a negative ozone anomaly in the East Siberian ozone maximum in winter and spring of 1995 , Meteorologiia $i$ Gidrologiia, 6, 53-62, 1996.

Goutail, F., Pommereau, J.-P., Sarkissian, A., Kyro, E., and Dorokhov, V.: Total nitro25 gen dioxide at the Arctic polar circle since 1990, Geophys. Res. Lett., 21, 1371-1374, doi:10.1029/93GL01783, 1994.

Goutail, F., Pommereau, J.-P., Lefèvre, F., van Roozendael, M., Andersen, S. B., Kåstad Høiskar, B.-A., Dorokhov, V., Kyrö, E., Chipperfield, M. P., and Feng, W.: Early unusual ozone loss during the Arctic winter 2002/2003 compared to other winters, Atmos. Chem. Phys., 5, 665-677, doi:10.5194/acp-5-665-2005, 2005.

Hendrick, F., Pommereau, J.-P., Goutail, F., Evans, R. D., Ionov, D., Pazmino, A., Kyrö, E., Held, G., Eriksen, P., Dorokhov, V., Gil, M., and Van Roozendael, M.: NDACC/SAOZ
AMTD

6, 2955-2978, 2013

Arctic ozone loss in Siberia in 2011 and 2012

V. Dorokhov et al.

\section{Title Page}

Abstract

Conclusions

References

Tables

Figures

14

DI

4

Back

$>$

Close

\section{Full Screen / Esc}

Printer-friendly Version

Interactive Discussion 
UV-visible total ozone measurements: improved retrieval and comparison with correlative ground-based and satellite observations, Atmos. Chem. Phys., 11, 5975-5995, doi:10.5194/acp-11-5975-2011, 2011.

Kerr, J. B., McElroy, C. T., Wardle, D. I., and Dorokhov, V.: Measurements of Arctic total ozone 5 during the polar winter, Atmos. Ocean, 28, 383-392, doi:10.1080/07055900.1990.9649384, 1990.

Manney, G. L., Froidevaux, L., Waters, J. W., Zurek, R. W., Read, W. G., Elson, L. S., Kumer, J. B., Mergenthaler, J. L., Roche, A. E., O'Neill, A., Harwood, R. S., MacKenzie, I., and Swinbank, R.: Chemical depletion of ozone in the Arctic lower stratosphere during winter 1992-1993, Nature, 370, 429-434, doi:10.1038/370429a0, 1994.

Manney, G. L., Zurek, R. W., Froidevaux, L., and Waters, J. W.: Evidence for Arctic ozone depletion in late February and early March 1994, Geophys. Res. Lett., 22, 2941-2944, doi:10.1029/95GL02229, 1995.

Manney, G. L., Santee, M. L., Rex, M., Livesey, N. J., Pitts, M. C., Veefkind, P., Nash, E. R., 15 Wohltmann, I., Lehmann, R., Froidevaux, L., Poole, L. R., Schoeberl, M. R., Haffner, D. P., Davies, J., Dorokhov, V., Gernandt, H., Johnson, B., Kivi, R., Kyro, E., Larsen, N., Levelt, P. F., Makshtas, A., McElroy, C. T., Nakajima, H., Parrondo, M. C., Tarasick, D. W., von der Gathen, P., Walker, K. A., and Zinoviev, N. S.: Unprecedented Arctic ozone loss in 2011, Nature, 478, 469-475, doi:10.1038/nature10556, 2011.

20 Nerushev, A. F. and Tereb, N. V.: Comparison of ground-based and satellite measurements of surface ultraviolet radiation exposures for the Central European region of Russia, Earth Res. Space, 5, 35-42, 2003.

Pommereau, J. P. and Goutail, F.: $\mathrm{O}_{3}$ and $\mathrm{NO}_{2}$ ground-based measurements by visible spectrometry during Arctic winter and spring 1988, Geophys. Res. Lett., 15, 891-894, 25 doi:10.1029/GL015i008p00891, 1988.

Pommereau, J.-P., Goutail, F., Lefèvre, F., Pazmino, A., Adams, C., Dorokhov, V., Eriksen, P., Kivi, R., Stebel, K., Zhao, X., and van Rozendael, M.: Why unprecedented ozone loss in the Arctic in 2011? Is it related to climatic change?, Atmos. Chem. Phys. Discuss., 13, 311-343, doi:10.5194/acpd-13-311-2013, 2013.

so Rex, M., Harris, N. R. P., von der Gathen, P., Lehmann, R., Braathen, G. O., Reimer, E., Beck, A., Chipperfield, M. P., Alfier, R., Allaart, M., O'Connor, F., Dier, H., Dorokhov, V., Fast, H., Gil, M., Kyrö, E., Litynska, Z., Mikkelsen, I. S., Molyneux, M. G., Nakane, H.,

\section{AMTD}

6, 2955-2978, 2013

Arctic ozone loss in Siberia in 2011 and 2012

V. Dorokhov et al.

\section{Title Page}

Abstract Introduction

Conclusions

Tables

References

Figures
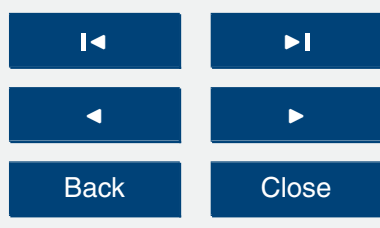

Back

Close

\section{Full Screen / Esc}

Printer-friendly Version

Interactive Discussion 
Notholt, J., Rummukainen, M., Viatte, P., and Wenger, J.: Prolonged stratospheric ozone loss in the 1995-96 Arctic winter, Nature, 389, 835-838, doi:10.1038/39849, 1997.

Rex, M., Salawitch, R. J., Deckelmann, H., von der Gathen, P., Harris, N. R. P., Chipperfield, M. P., Naujokat, B., Reimer, E., Allaart, M., Andersen, S. B., Bevilacqua, R., Braathen, G. O., Claude, H., Davies, J., De Backer, H., Dier, H., Dorokhov, V., Fast, H., Gerding, M., Hoppel, K., Johnson, B., Kyrö, E., Litynska, Z., Moore, D., Nagai, T., Parrondo, M. C., Risley, D., Skrivankova, P., Stübi, R., Trepte, C., Viatte, P., and Zerefos, C.: Arctic winter 2005: implications for stratospheric ozone loss and climate change, Geophys. Res. Lett., 33, L23808, doi:10.1029/2006GL026731, 2006.

10 Solomon, S.: Stratospheric ozone depletion: a review of concepts and history, Rev. Geophys., 37, 275-316, doi:10.1029/1999RG900008, 1999.

Sugita, T., Nakajima, H., Yokota, T., Kanzawa, H., Gernandt, H., Herber, A., von der Gathen, P., König-Langlo, G., Sato, K., Dorokhov, V., Yushkov, V. A., Murayama, Y., Yamamori, M., GodinBeekmann, S., Goutail, F., Roscoe, H. K., Deshler, T., Yela, M., Taalas, P., Kyrö, E., Oltmans, S. J., Johnson, B. J., Allaart, M., Litynska, Z., Klekociuk, A., Andersen, S. B., Braathen, G. O., De Backer, H., Randall, C. E., Bevilacqua, R. M., Taha, G., Thomason, L. W., Irie, H., Ejiri, M. K., Saitoh, N., Tanaka, T., Terao, Y., Kobayashi, H., and Sasano, Y.: Ozone profiles in the high-latitude stratosphere and lower mesosphere measured by the Improved Limb Atmospheric Spectrometer (ILAS)-II: comparison with other satellite sensors and ozonesondes, J. Geophys. Res., 111, D11S02, doi:10.1029/2005JD006439, 2006.

20

Tsvetkova, N. D., Yushkov, V. A., Dorokhov, V. M., and Zaitcev, I. G.: Some results of measurements of vertical ozone distribution over Yakutsk during the 1995-96, Meteorologiia $i$ Gidrologiia, 9, 45-51, 1997.

Tsvetkova, N. D., Nakane, H., Lukyanov, A. N., Yushkov, V. A., Dorokhov, V. M., Zaitsev, I. G., 25 and Sitnikova, V. I.: Estimation of the winter-spring rates of ozone depletion within the stratospheric Arctic cyclone in Siberia in 1995-2000 from balloon measurements, Izv. Atmos. Ocean. Phy+, 38, 184-192, 2002.

Tsvetkova, N. D., Yushkov, V. A., Lukyanov, A.N, Dorokhov, V. M., and Nakane, H.: Recordbreaking chemical destruction of ozone in the Arctic during the winter of 2004/2005, Izv.

$30 \quad$ Atmos. Ocean. Phy+, 43, 592-598, doi:10.1134/S0001433807050076, 2007.

von der Gathen, P., Rex, M., Harris, N. R. P., Lucic, D., Knudsen, B. M., Braathen, G. O., Backer, H. D., Fabian, R., Fast, H., Gil, M., Kyrö, E., Mikkelsen, I. S., Rummukainen, M.,

\section{AMTD}

6, 2955-2978, 2013

Arctic ozone loss in Siberia in 2011 and 2012

V. Dorokhov et al.

\section{Title Page}

Abstract

Introduction

Conclusions

Tables

References

Figures

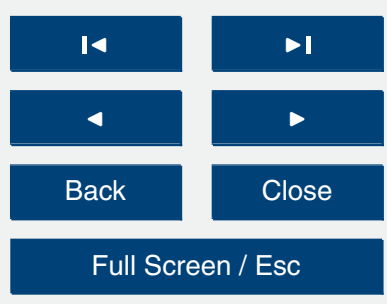

Printer-friendly Version

Interactive Discussion 
Stähelin, J., and Varotsos, C.: Observational evidence for chemical ozone depletion over the Arctic in winter 1991-92, Nature, 375, 131-134, doi:10.1038/375131a0, 1995.

Yushkov, V. A., Nakane, H., Tsvetkova, N. D., Dorokhov, V. M., Sitnikova, V. I., and Lukyanov, A. N.: Investigation of ozone loss during winter-spring period of 2000 using data of balloon measurements and ground-based observations in Siberia, Meteorologiia $\mathrm{i}$ Gidrologiia, 12, 27-35, 2002.

WMO: Scientific Assessment of Ozone Depletion: 2006, Global Ozone Research and Monitoring Project-Report No. 52, World Meteorological Organisation, Geneva, Switzerland, 516 pp., 2011.

\section{AMTD}

6, 2955-2978, 2013

Arctic ozone loss in Siberia in 2011 and 2012

V. Dorokhov et al.

Title Page

Abstract

Introduction

Conclusions

References

Tables

Figures

14

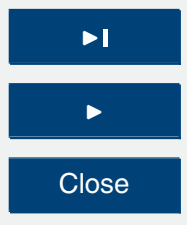

Back

Close

Full Screen / Esc

Printer-friendly Version

Interactive Discussion 


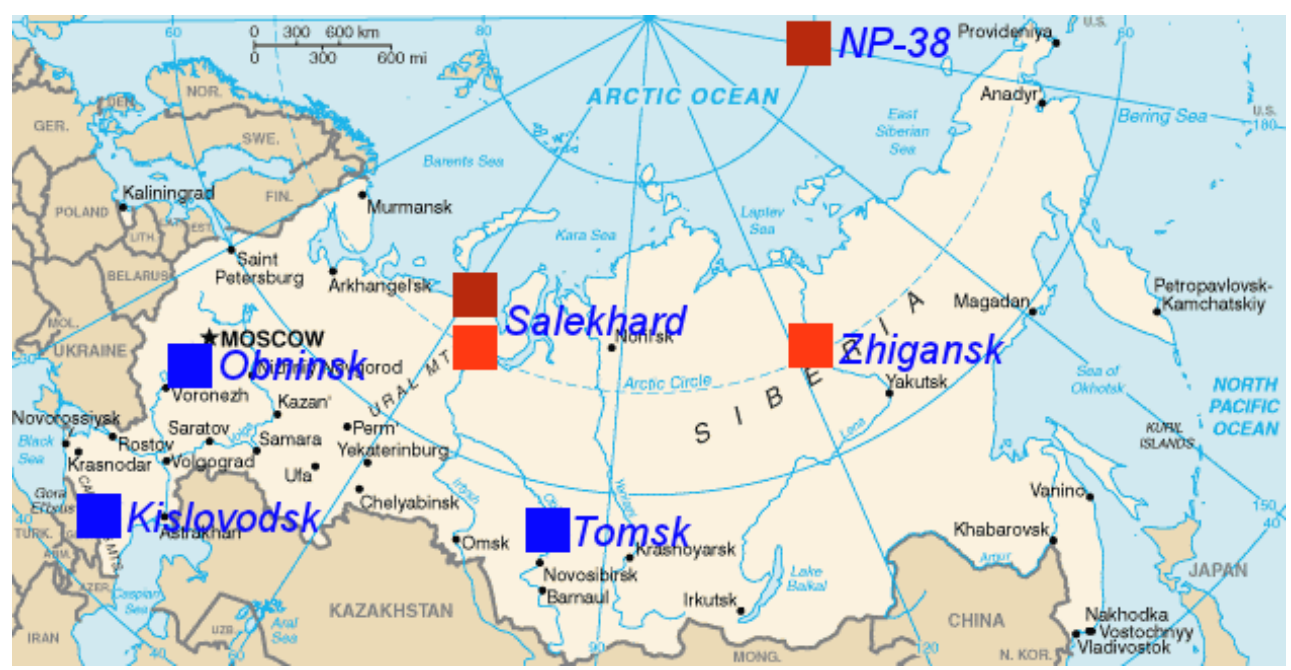

Brewer $\square$ SAOZ $\square$ sonde

Fig. 1. The location of the Brewer, SAOZ and ozonesonde stations in Russia.

\section{AMTD}

6, 2955-2978, 2013

Arctic ozone loss in Siberia in 2011 and 2012

V. Dorokhov et al.

\section{Title Page}

Abstract

Introduction

Conclusions

References

Tables

Figures

14

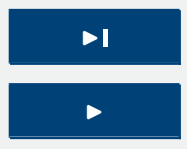

Back

Close

Full Screen / Esc

Printer-friendly Version

Interactive Discussion

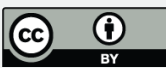




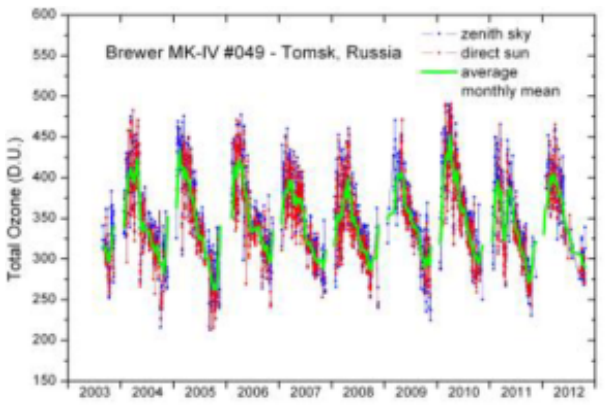

(a)

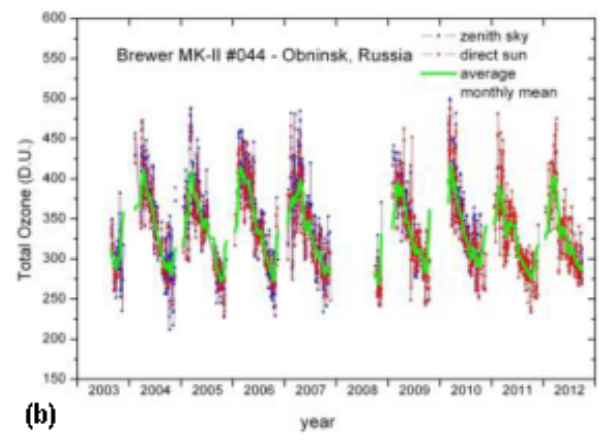

Fig. 2. The result of the Brewer MKIV No 049 total ozone measurements in Tomsk in 20032012 (a) and Brewer MKII No 044 total ozone observations in Obninsk in 2003-2012 (b).

\section{AMTD}

6, 2955-2978, 2013

Arctic ozone loss in Siberia in 2011 and 2012

V. Dorokhov et al.

\section{Title Page}

Abstract

Introduction

Conclusions

References

Tables

Figures

14

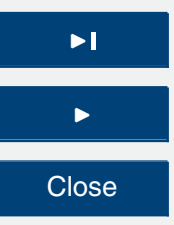

Back

Close

Full Screen / Esc

Printer-friendly Version

Interactive Discussion 

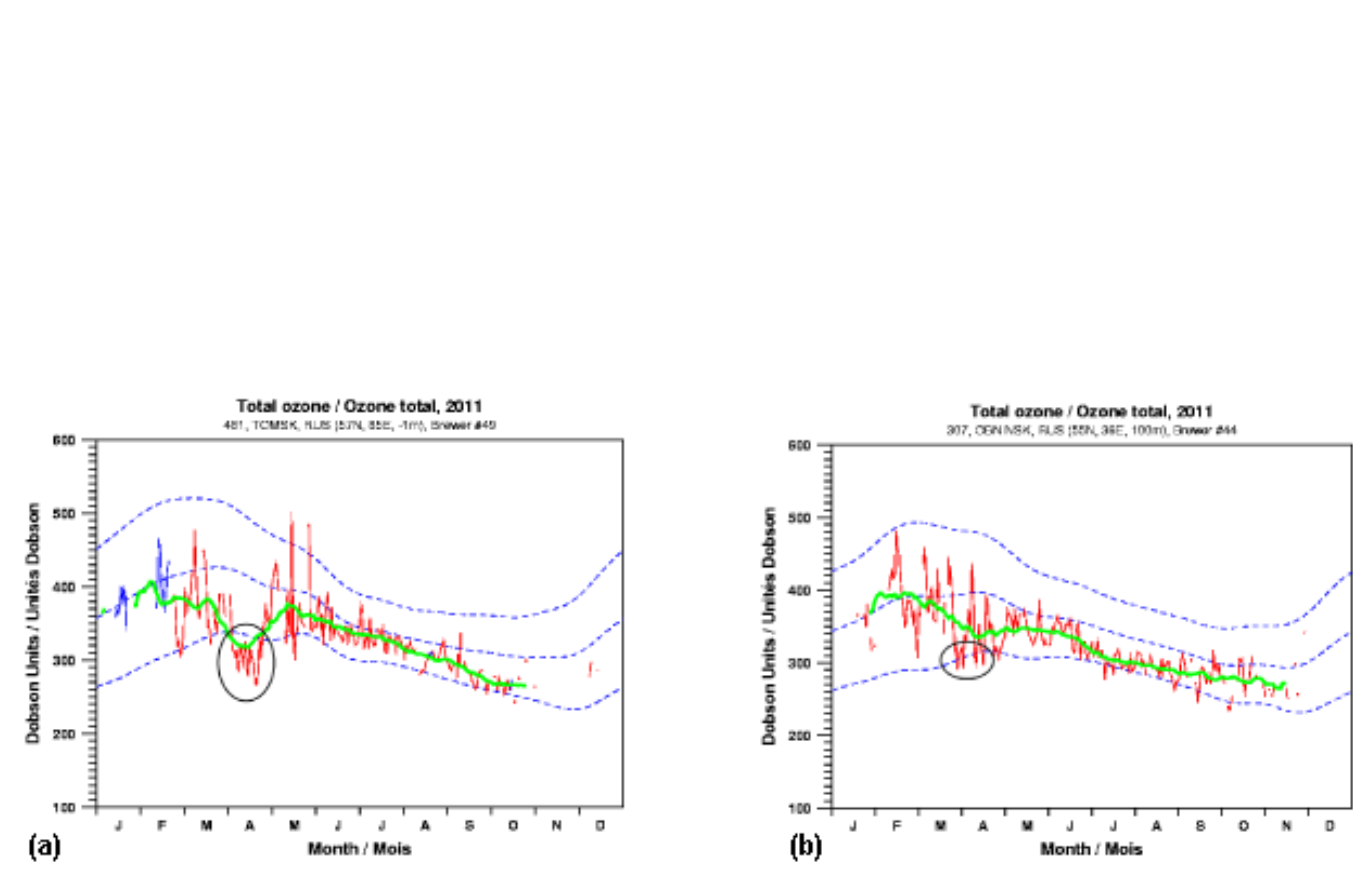

\section{AMTD}

6, 2955-2978, 2013

\section{Arctic ozone loss in Siberia in 2011 and 2012}

V. Dorokhov et al.

Title Page

\section{Abstract}

Introduction

Conclusions

References

Tables

Figures

Fig. 3. The result of the Brewer MKIV No 049 total ozone measurements in Tomsk in 2011 (a) and the Brewer MKII No 044 total ozone measurements in Obninsk in 2011 (b). The initial plots are from the WOUDC database http://www.woudc.org/data_e.html.

14

4

Back

Full Screen / Esc

Printer-friendly Version

Interactive Discussion 


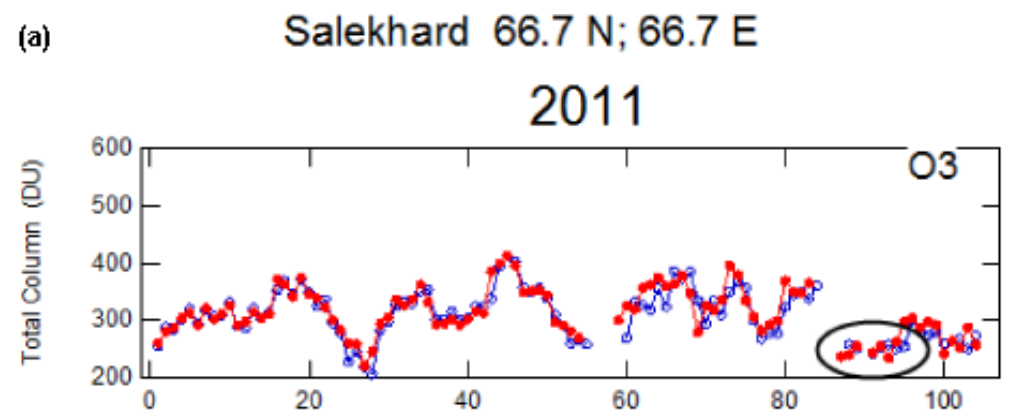

\section{AMTD}

6, 2955-2978, 2013

\section{Arctic ozone loss in Siberia in 2011 and 2012}

V. Dorokhov et al.

(b)

Zhigansk $66.8 \mathrm{~N} ; 123.4 \mathrm{E}$

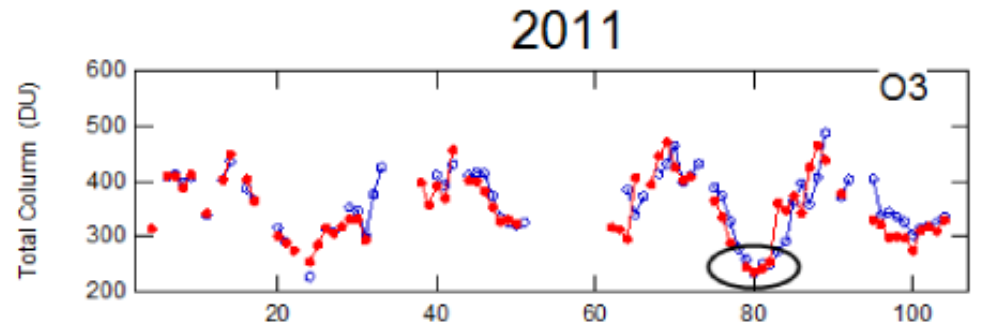

Fig. 4. SAOZ spectrometerr total ozone real-time data at the Salekhard aerological station (a) and at the Zhigansk aerological station (b) in January-April 2011. The initial plots are from the World SAOZ real time database http://saoz.obs.uvsq.fr/SAOZ-RT.html.

Title Page

Abstract

Introduction

Conclusions

References

Tables

Figures

14

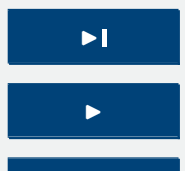

Back

Close

Full Screen / Esc

Printer-friendly Version

Interactive Discussion 


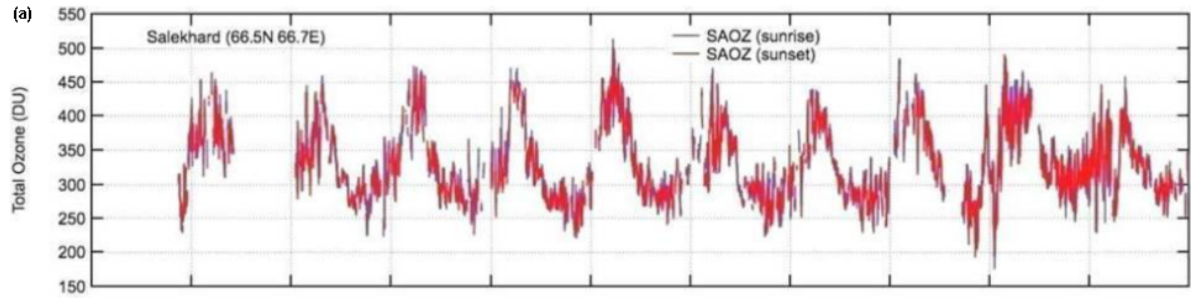

AMTD

6, 2955-2978, 2013
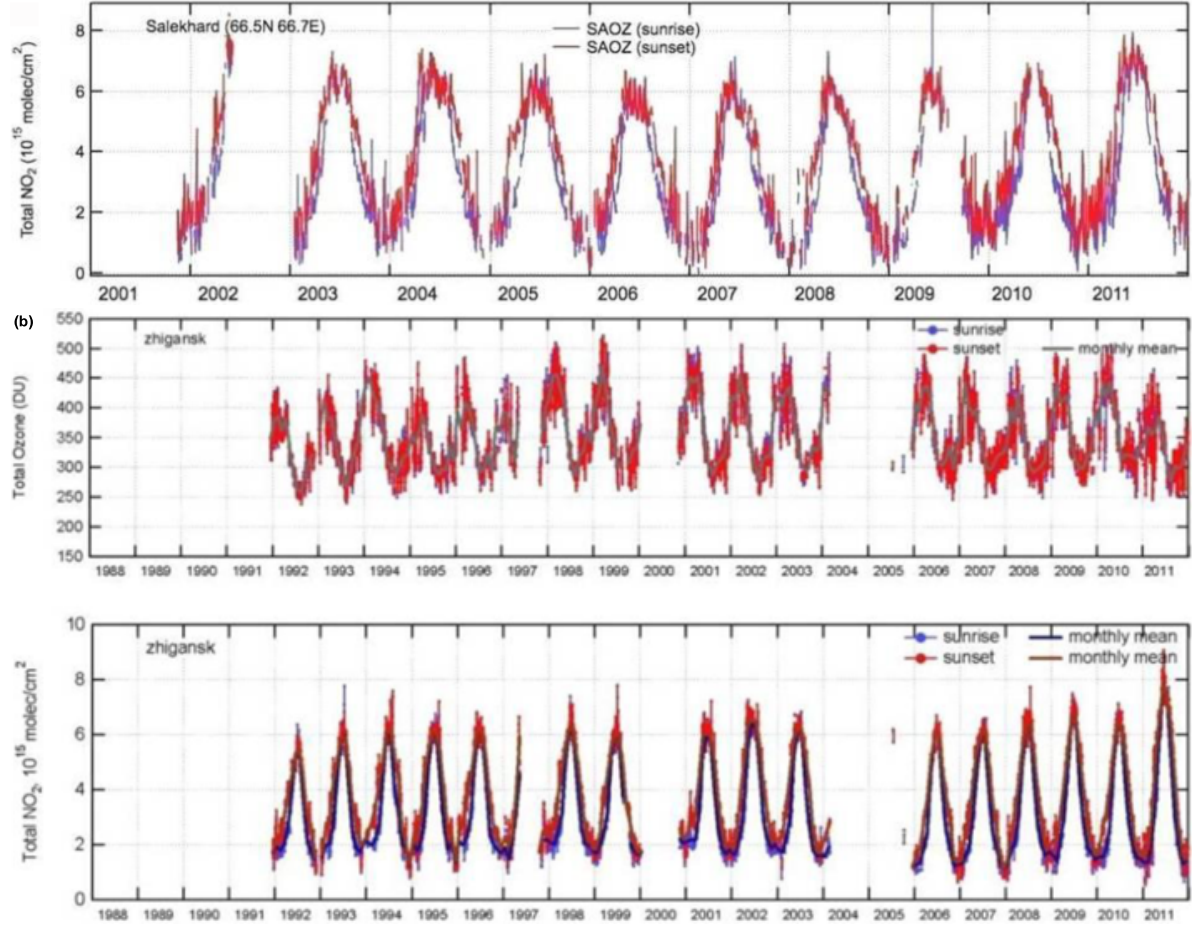

Fig. 5. The long-term series of $\mathrm{SAOZ}$ total ozone and $\mathrm{NO}_{2}$ measurements at Salekhard aerological station in 2001-2011 (a) and at Zhigansk aerological station in 1991-2011 (b).

Arctic ozone loss in Siberia in 2011 and 2012

V. Dorokhov et al.

Title Page

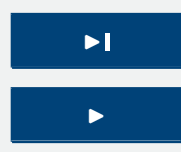

\section{Full Screen / Esc}

Printer-friendly Version

Interactive Discussion

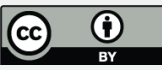



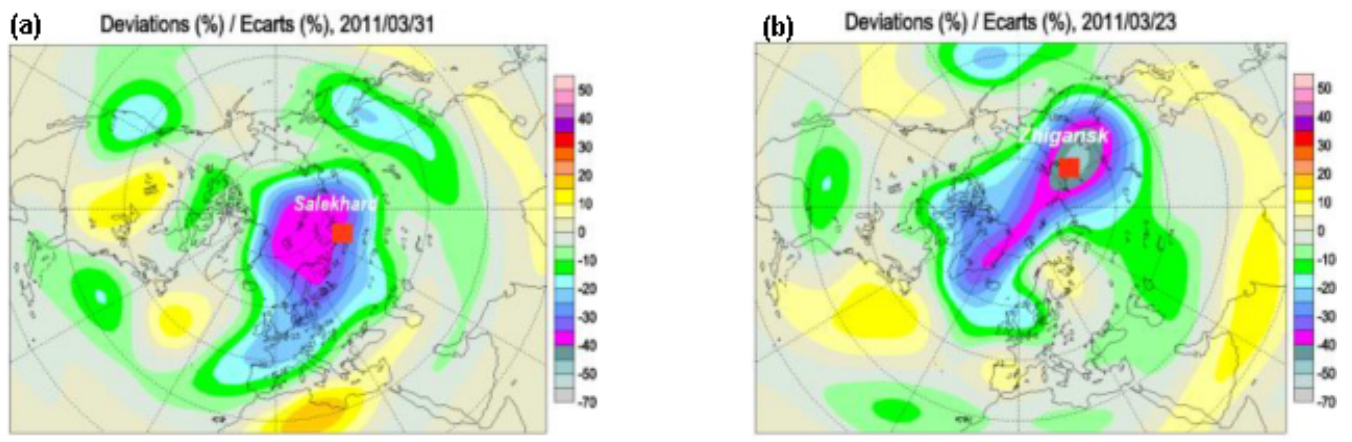

Fig. 6. WOUDC total ozone mapping on 23 and 31 March 2011 when the low ozone vortex passed over Salekhard (a) and Zhigansk (b). The initial plots of the total ozone deviation are from the WOUDC database http://www.woudc.org/data_e.html.

\section{AMTD}

6, 2955-2978, 2013

Arctic ozone loss in Siberia in 2011 and 2012

V. Dorokhov et al.

\section{Title Page}

Abstract

Introduction

Conclusions

References

Tables

Figures

14

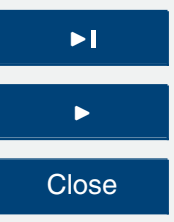

Back

Close

Full Screen / Esc

Printer-friendly Version

Interactive Discussion 

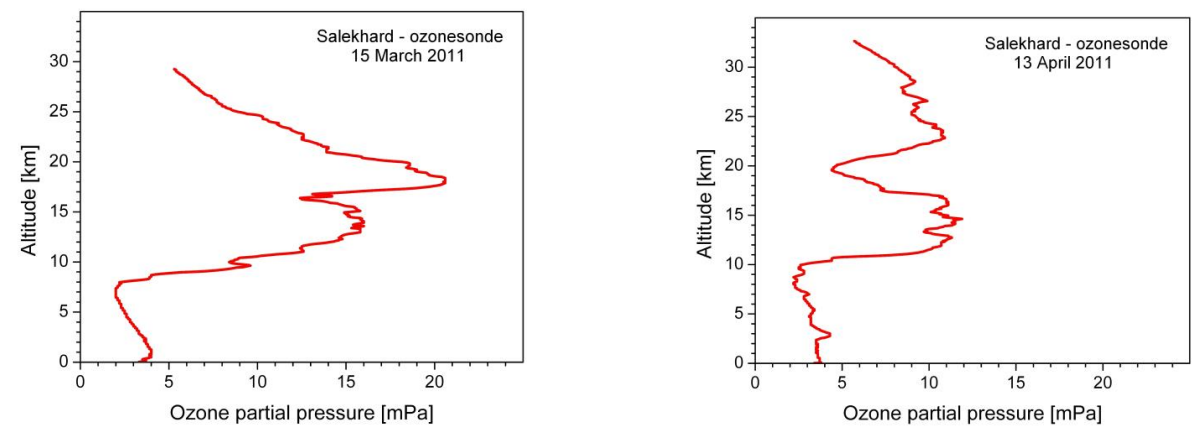

AMTD

6, 2955-2978, 2013

\section{Arctic ozone loss in Siberia in 2011 and 2012}

V. Dorokhov et al.
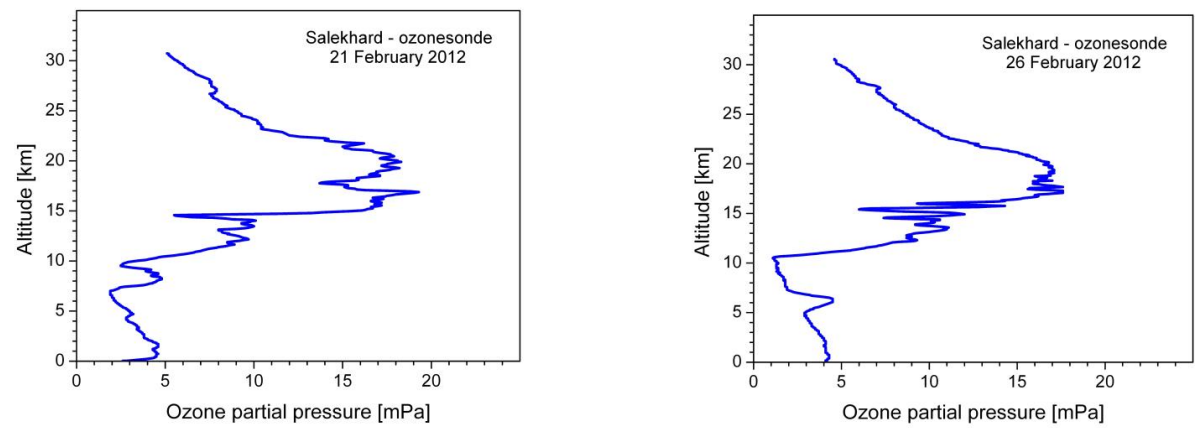

Title Page

Abstract

Introduction

Conclusions

References

Tables

Figures

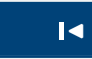

14

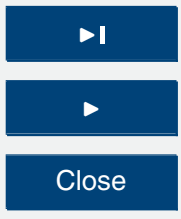

Back

Close

Full Screen / Esc

Fig. 7. Ozone profiles from 2Z-ECC sondes in Salekhard in the polar vortex in March-April 2011 (red) and in February 2012 (blue).

Printer-friendly Version

Interactive Discussion

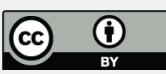

